\title{
Atkafélék okozta, bőrtünetekkel járó humán megbetegedések
}

\author{
Budai Dóra dr. ${ }^{1}$ - Barna Tibor dr. ${ }^{2}$ - Nagy Gabriella dr. ${ }^{1}$ \\ ${ }^{1}$ Borsod-Abaúj-Zemplén Megyei Központi Kórház és Egyetemi Oktatókórház, Bőrgyógyászati Osztály, Miskolc \\ ${ }^{2}$ Borsod-Abaúj-Zemplén Megyei Központi Kórház és Egyetemi Oktatókórház, Patológiai Osztály, Miskolc
}

\begin{abstract}
Az atkák alosztálya heterogén csoport. Az eltérő megjelenésú és életformájú atkák növényeken, állatokon és embereken is képesek különféle megbetegedéseket okozni, melyek csípés, táplálkozás, élősködés, vektorként terjesztett kórokozók által valósulhatnak meg. Az atkák okozta betegségek a lokális, spontán szűnő csípéstől egészen a sokszervi elégtelenséget okozó fertőző betegségig széles skálán mozognak. Munkánk során az atkafélék által okozott humán megbetegedések előfordulását, klinikai megjelenését, differenciáldiagnosztikáját, kezelését és közegészségügyi jelentőségét mutatjuk be.
\end{abstract}

Orv Hetil. 2021; 162(36): 1430-1437.

Kulcsszavak: Acari, atkák, kullancsok

\section{Acari-caused human diseases with skin symptoms}

The Acari subclass is a heterogeneous group. They have different appearance and lifestyle. They can cause different diseases on plants, in animals and in humans. These illnesses can be caused by their bites, nutrition, parasitism and by their endoparasites. The diseases move on a wide scale from a local, spontaneously disappearing bite to an infection caused multiorgan failure. We would like to summarize the Acari-caused human diseases' incidence, clinical symptoms, diagnostics, differential diagnostics, treatments and public health importance.

Keywords: Acari, mites, ticks

Budai D, Barna T, Nagy G. [Acari-caused human diseases with skin symptoms]. Orv Hetil. 2021; 162(36): 14301437.

(Beérkezett: 2020. december 29.; elfogadva: 2021. március 3.)

\section{Rövidítések}

ELISA $=$ (enzyme-linked immunosorbent assay) enzimhez kapcsolt immunszorbensteszt; HIV = (human immunodeficiency virus) emberi immunhiányt előidéző vírus; $\operatorname{IgE}=$ immunglobulin-E

Az atkák alosztálya az ízeltlábúak törzse csáprágósok altörzsének pókszabásúak osztályához tartozik, mely igen változatos csoport $[1,2]$. Tagjai többnyire parányi, szelvényezetlen testüek [2]. Élőhelyük és életmódjuk sokféle. Testtagolódásuk bonyolult $[1,2]$. Négy rendjük ismert (rühatkaalakúak, bársonyatka-alakúak, kullancsalakúak, nyügatkaalakúak), melyek számos családra, nemzetségre tagolódnak. Három jelentősen eltérő rendje okoz heterogén humán megbetegedéseket (1. táblá- zat) [1-4]. A különböző földrajzi lokalizációkban honos atkafélék meghatározott hőmérsékleten és páratartalom mellett életképesek, így az általuk okozott, gyakran megtévesztő klinikai képpel járó betegségek diagnosztizálásában kiemelt jelentőségü a tünetek mellett az utazásokra, a szabadidős tevékenységekre kiterjedő részletes anamnézis. A szemmel gyakran nem látható atkák azonosításában a mikroszkóp és a dermatoszkóp nyújthat további segítséget. A vektorként terjesztett kórokozók esetén a szerológiai vizsgálatoknak jut kiemelt szerep [3, 4]. Munkánk során - hangsúlyozva a Magyarországon megjelenő - atkafélék okozta heterogén betegségek előfordulását, tünettanát, differenciáldiagnosztikáját, kezelését és közegészségügyi jelentőségét mutatjuk be rendszertani felosztás (családok) alapján [2-4]. 
Az atkák alosztályának humán megbetegedéseket okozó rendjei, családjai és nemzetségei [1-4]

\begin{tabular}{lll}
\hline Rend & Család & Nemzetség \\
\hline Rühatkaalakúak & Rühatkafélék & Sarcoptes (rühatka) \\
& Poratkafélék & $\begin{array}{l}\text { Dermatophagoides } \\
\text { (háziporatka) }\end{array}$ \\
& Készletatkafélék & Acarus (készletatka) \\
\hline $\begin{array}{l}\text { Bársonyatka- } \\
\text { alakúak }\end{array}$ & Bársonyatkafélék & Trombicula (bársonyatka) \\
& Szőrtüszőatka-félék & Demodex (szörtüszóatka) \\
& Szóratkafélék & Cheyletiella \\
\hline Kullancsalakúak & Kullancsfélék & Amblyomma \\
& & Bothriocroton \\
& & Dermacentor \\
& & Haemaphysalis \\
& & Hyalomma \\
& & Ixodes \\
& & Rhipicephalus \\
& &
\end{tabular}

\section{A rühatkafélék családja}

A Sarcoptes scabiei varietas hominis a rühatka humán variánsa, mely emberen a scabiest, vagyis a rühességet okozza. Ez elterjedt betegség, becsült prevalenciája a világon 300 millió, Magyarországon is gyakori $[5,6]$. Továbbításában a közvetlen kontaktusnak, ruháknak, ágynemúnek van szerepe. Megfelelő higiénés szokások mellett is bárkit érinthet, de gyakrabban fordul elő rossz szociális körülmények között élőkön [6]. Kisebb járványokat alakíthat ki zsúfolt helyeken, idősek otthonában, ápolási osztályokon és hajléktalanszállókon. Lappangási ideje néhány hét. A 0,3 mm-es atkák az epidermisben keskeny, hullámos járatokat képeznek (1.ábra). Jellemzője a kínzó, fóként éjszaka jelentkező viszketés. A klasszikus scabies jellegzetes bőrtünetei az erythemás papulák, a pont-

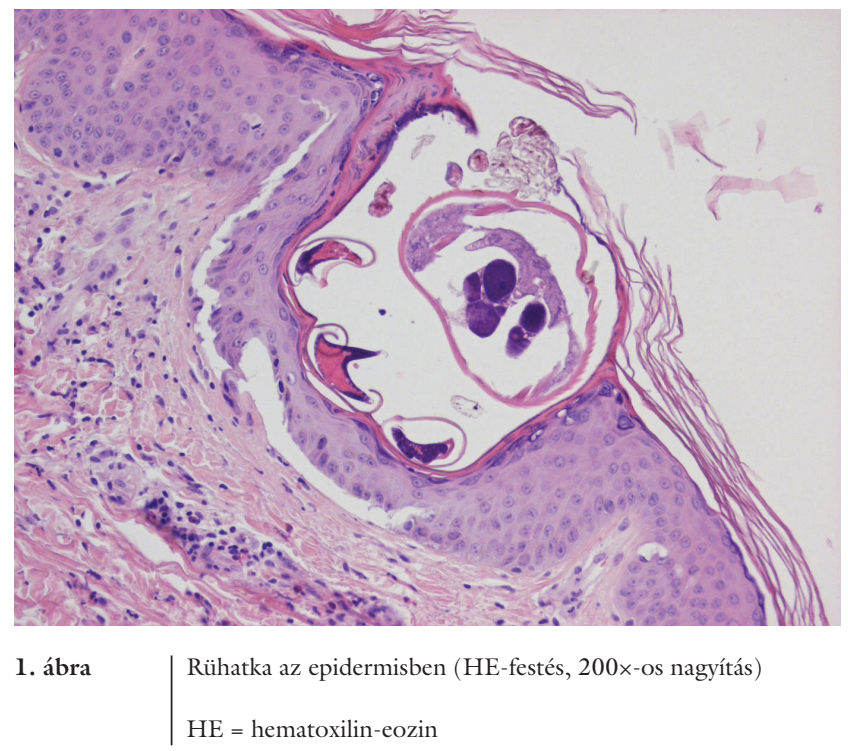

szerú és vonalas excoriatiók, melyek a leggyakrabban a kézujjak között, a csuklók hajlítófelszínein, a könyökökön, a hónaljakban, a nemi szerven, a fartájékon és a törzs két oldalán jelentkeznek (2. ábra) [3]. A scabies ritkán észlelhető körömtüneteire jellemző a megvastagodás, a szürkéssárga elszíneződés, a dystrophia, a subungualis lerakódás, továbbá a körömlemez lamellaris és longitudinális szétválása [7]. A diagnózis felállításában a klinikai kép az elsődleges. Dermatoszkóppal atkajáratok, bennük atkák és peték láthatók, melyek kálium-hidroxidmetodika segítségével, a hámkaparék fénymikroszkópos vizsgálatával direkt módon is kimutathatók. Tuspróbával a tinta lemosását követően a járatok kirajzolódnak a bőrön. Laboratóriumi vizsgálattal gyakran eosinophilia észlelhető $[3,8]$.

Scabieshez hasonló klinikai képpel járhat az atopiás dermatitis, az exsiccatiós dermatitis (ekzema craquelé), az ótvar (impetigo contagiosa) és a dermatitis herpetifor-

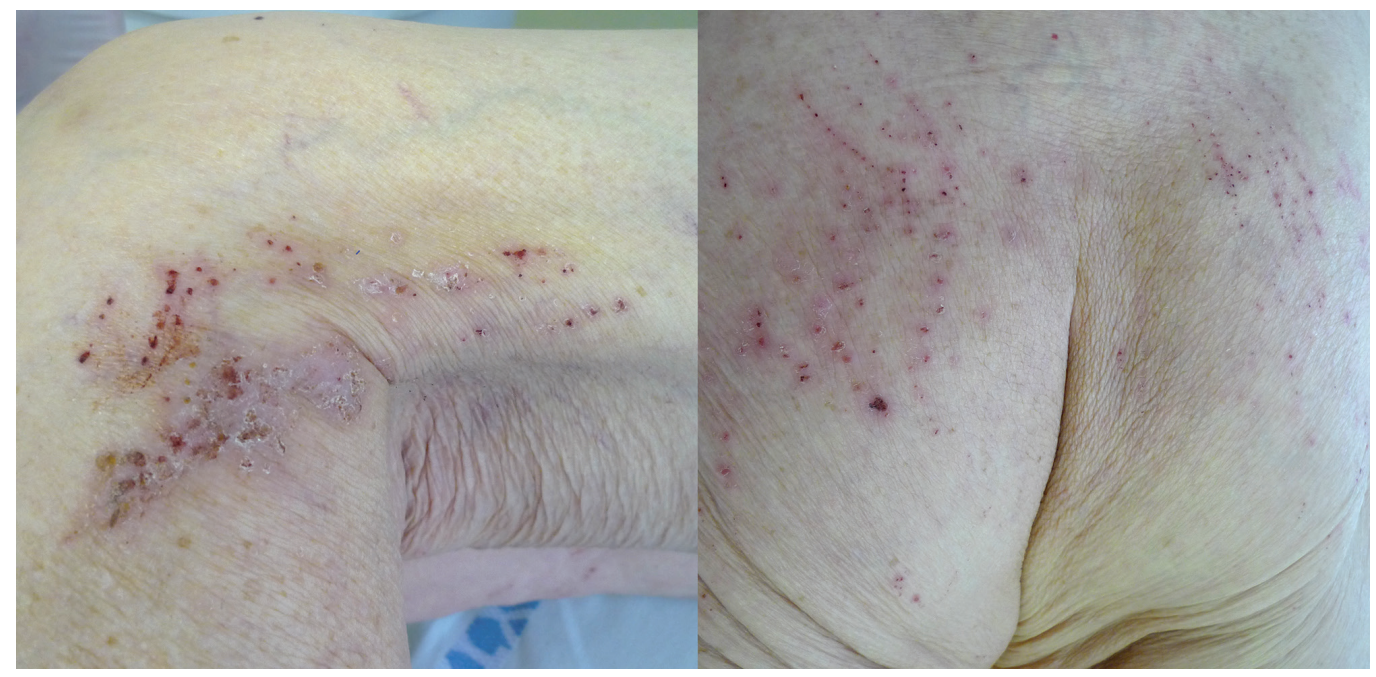




\section{2. táblázat $\mid$ A scabies kezelése $[5,11,14]$}

\begin{tabular}{|c|c|c|}
\hline \multirow[t]{5}{*}{$\begin{array}{l}\text { Lokális } \\
\text { kezelés }\end{array}$} & $\begin{array}{l}\text { 25-30\%-os benzil-benzoát- } \\
\text { emulzió }\end{array}$ & 24 órán át két rétegben \\
\hline & $\begin{array}{l}\text { 30\% benzil-benzoát- + 1\% } \\
\text { dimetil-ftalát-tartalmú } \\
\text { emulzió }\end{array}$ & \\
\hline & $\begin{array}{l}10 \%-\text { os }(5-15 \%) \text { kéntartal- } \\
\text { mú kenőcs }\end{array}$ & $\begin{array}{l}\text { 3-5 napig éjjelre, vagy } \\
2-3 \text { óránként nappalra }\end{array}$ \\
\hline & 5\%-os permetrinkrém & $\begin{array}{l}1 \text { alkalommal } 8 \text { órán } \\
\text { keresztül }\end{array}$ \\
\hline & $\begin{array}{l}\text { 10\%-os krotamitonkrém } \\
\text { (Magyarországon nincs } \\
\text { forgalomban) }\end{array}$ & 48 órán át két rétegben \\
\hline $\begin{array}{l}\text { Szisztémás } \\
\text { kezelés }\end{array}$ & $\begin{array}{l}\text { Ivermektin } 200 \mu \mathrm{g} / \mathrm{ttkg} \\
\text { (Magyarországon nincs } \\
\text { forgalomban) }\end{array}$ & Egyszeri dózis \\
\hline
\end{tabular}

mis Duhring. Diabeteshez, vesebetegséghez vagy májbetegséghez társuló pruritus esetén scabiesszerú prurigók és excoriatiók figyelhetők meg [3]. Gyermekeknél a Langerhans-sejtes histiocytosis, infantilis acropustulosis és vírusexanthemák merülnek fel differenciáldiagnózisként [9]. Fontos kiemelni, hogy a rühesség hajlamosít a szekunder pyogen szuperinfekcióra. Impetiginizálódott, atípusos klinikai kép esetén a sebváladék-tenyésztés és a bőrbiopszia szövettani vizsgálata segíthet a diagnózis felállításában $[3,8]$. A scabies ritka körömtüneteihez az onychomycosis és az acrodermatitis continua suppurativa Hallopeau körömtünetei hasonlíthatnak [7].

A rühességnek több formája ismert. A scabies norvegica (crustosus scabies) kifejezetten fertőző variáns. Az atkák nagymértékben elszaporodnak, akár több millióan is jelen lehetnek a bőrön. Lappangási ideje 10-14 napra rövidül $[3,10]$. Kialakulásában hajlamosító tényezők az immunszuppresszív állapotok (például HIV-fertőzés, malignus hematológiai betegségek, kemoterápia), az időskor, a Down-szindróma, az önellátás képességének hiánya és a malnutritio [11]. Viszkető, nagy méretű, sárgásfehéren hámló, hyperkeratoticus plakkok, crustosus felrakódások jellemzik. Fő lokalizációi az arc, a fülkagylók, az interdigitalis vagy a genitalis területek, de megjelenhet a betegség konfluáló papulosus erupciók formájában is. A bőrtünetek másodlagos szuperinfekciója szeptikus állapothoz, az atípusos klinikai tünetek miatt a késleltetett diagnózis nosocomialis járványok kialakulásához vezethet $[3,10,11]$. Differenciáldiagnosztikai szempontból a crustosus scabies esetében elsősorban psoriasis, ichthyosis, lymphoproliferativ betegségek, generalizált ekzema, prurigo, kontaktdermatitis vagy Darier-betegség jön szóba [11].

A scabies incognito ápolt egyéneken vagy szteroid externa alkalmazása mellett alakulhat ki. Nehezen felismerhető, klinikai képe atípusos [3].

A scabies nodularis szintén „tiszta” bőrön, illetve gyermekkorban fordul elő. Jól körülírt csomók láthatók föként a genitalis, inguinalis és axillaris régiókban.
Kezelést követően a nodusok hetekig megmaradhatnak $[3,12]$.

A bullosus scabies ritkán észlelhetô hólyagos tünetei autoimmun hólyagos bőrbetegségeket utánozhatnak [13].

A rühesség kezelése elsősorban lokális (2. táblázat) [5, 11, 14]. A benzil-benzoát hatástalansága esetén permetrin alkalmazható helyileg. Semmelweis Tagkórházunkban 2005-ben hematológiai osztályról kiinduló nosocomialis scabiesjárvány során a betegek egy részénél a benzil-benzoát szintén hatástalannak bizonyult, egyedi engedély alapján Hollandiából behozott, $200 \mu \mathrm{g} / \mathrm{ttkg}$ ivermektin egyszeri dózisa segített a járvány felszámolásában [11]. Viszketéscsillapításra per os antihisztamin, kezelést követően fellépő bőrirritáció esetén lokális, kortikoszteroidtartalmú kenőcsök alkalmazandók [9]. A beteg mellett a tünetmentes kontaktok, szobatársak, családtagok egyidejű kezelése szükséges a pingpongeffektus megelőzéséért [3]. Fontos a környezet megfelelő dekontaminálása, az ágynemúk, ruhák, törülközők gyakori cseréje, magas hőfokon való mosása, vasalása. A szőnyegeket, a textíliával borított, kárpitozott bútorokat javasolt kiporszívózni. A nem mosható használati anyagokat néhány napra múanyag zsákba kell tenni, amíg az atkák élelem hiányában elpusztulnak $[6,9]$.

A nem humán rühatkák (például Sarcoptes scabiei varietas bovis, Sarcoptes scabiei varietas canis, Sarcoptes scabiei varietas cuniculi) emlősökön okoznak viszkető, erythemás exanthemákat, valamint szőrvesztést. A legtöbbször kutyák által közvetítve, véletlenszerúen juthatnak az emberre, ahol csak átmenetileg tartózkodnak, de nem szaporodnak. Ritkán a karokon és a törzsön viszkető, erythemás papulákat hoznak létre, melyek jellemzően spontán szünnek $[9,15]$.

\section{A poratkafélék családja}

A szemmel nem látható, néhány tized milliméteres háziporatkák a lehámlott bőrön élnek [3, 16]. Az egyes fajok előfordulása között földrajzi eltérések vannak [16, 17]. A világon a legelterjedtebb a Dermatophagoides pteronyssinus, melyet a Dermatophagoides farinae és az Euroglyphus maynei, majd a Dermatophagoides microceras követ a gyakorisági sorban. Kedvez számukra a magasabb páratartalom és a kevés fény, a körülményektől függően különböző fajai lehetnek jelen a lakásokban. Európában és hazánkban a leggyakrabban a Dermatophagoides pteronyssinus és a Dermatophagoides farinae található meg [18]. Testük és ürülékük számos major és minor allergént tartalmaz, melyek a háziporatka-túlérzékenység kialakulásáért felelősek [17]. Széles körben elfogadott feltételezés, hogy a világon a lakosság 1-2\%-ának lehet háziporatka-túlérzékenysége [18]. A beltéri aeroallergének közül a háziporatkák a legjelentősebbek [19]. Szerepet játszanak az allergiás kórképek közül az allergiás rhinitis, az allergiás asthma bronchiale, az atopiás dermatitis, 
az aerogén allergiás kontaktdermatitis és az ételallergia kialakulásában $[3,17]$.

A háziporatka-allergia diagnosztizálásának alapja a Prick-teszt. A használatban lévő kivonatok gyártónként különböző számban és arányban tartalmazhatják a Dermatophagoides pteronyssinus és a Dermatophagoides farinae egyes allergénjeit. Ezek jellemzően elegendőek a diagnózis felállításához [17]. Specifikus-IgE-vizsgálat indokolt, amennyiben Prick-teszt nem végezhető, az eredmény ellentmondásos, vagy specifikus immunterápia előtt a releváns allergén egyértelmú azonosítása szükséges [20]. A legtöbb minor és major allergén azonosítását a nehezebben elérhető, komponensalapú molekuláris diagnosztika teszi lehetővé [17]. Az atopiás dermatitis és az aerogén kontaktdermatitis esetén 'atopy patch' teszttel igazolható a háziporatka etiológiai szerepe [3]. Háziporatka-túlérzékenység kapcsán ételallergia-keresztreaktivitás által jön létre, melyet a tropomiozincsaládba tartozó fehérjék homológ epitópjai váltanak ki. Ugyanazon személynél így lehetséges háziporatka- és garnéla- (északi ostorgarnéla) túlérzékenység együttes fennállása [17].

Differenciáldiagnosztikailag az allergén azonosítása által az allergiás rhinitis és az allergiás asthma bronchiale elkülöníthető a nem allergiás típusaiktól [18, 20, 21]. A háziporatka-túlérzékenység miatt fellángoló atopiás dermatitis tünetei differenciálandók a nummularis ekzemáktól, a mycosisoktól, a scabiestől, a psoriasistól, a különböző etiológiájú erythrodermáktól és a dermatitis herpetiformis Duhringtól [22]. Az aerogén allergiás kontaktdermatitis a kontaktdermatitis különböző altípusaihoz és a photodermatosisokhoz hasonlíthat [3].

A háziporatka-túlérzékenység kiváltotta megbetegedések kezelésének alapja az allergén kerülése, a lakóhelyen az atkák számának csökkentése, amiben a betegoktatásnak és a betegtájékoztatásnak jut kiemelt szerep $[19,20]$. Fontos a tapéták és a padlószőnyeg mellőzése; az ágynemúk rendszeres cseréje, magas hőfokon való mosása; a párnák és a paplanok gyakori mosása, 1-5 ㅆm átmérőjü partikulumok kiszürésére is alkalmas anyagokkal való bevonása; a lakás és a fekhely többszöri porszívózása, a gyakori portörlés; a hőmérséklet $20^{\circ} \mathrm{C}$, a páratartalom 50\% alatt tartása [22]. Az allergiás kórképek kezelésének alapja a lokális és szisztémás antihisztamin, kortikoszteroid, illetve ezek kombinációja [20, 23-25]. Súlyos esetekben anti-IgE (omalizumab)-kezelésre van lehetőség, mely hazánkban allergiás asthma bronchiale és orrpolyposissal társuló krónikus rhinosinusitis terápiájára érhető el [26]. Szintén súlyos esetekben jön szóba az allergénspecifikus immunterápia $[19,25]$. Ételallergia esetén fontos az azonosított étel (garnéla) teljes kerülése, ugyanis súlyos tünetek - akár anaphylaxia - jelentkezhetnek $[17,27]$.

\section{A készletatkafélék családja}

Számos készletatka ismert, melyek fóként magas fehérjeés szénhidráttartalmú élelmiszereken fordulnak elő. Az élelmiszeren tenyésző penészgombákat és spóráikat fogyasztják. Jól lehet védekezni ellenük a felhalmozott készletek szárazon tartásával. A legismertebbek a hazánkban is elóforduló lisztatka (Acarus siro) és sajtatka (Tyrophagus casei) [2]. A készletatkák családjának számos tagja megtalálható a lakásban, lakásatkának is nevezik, illetve gyakran háziporatkákkal együtt említik őket $[17,18]$. A lakásban élő készletatkák közül a Glycyphagus domesticus és a Gobieria fusca jellemzően európai előfordulásúak [18]. Foglalkozással összefüggően és a lakóhelyünkön megtalálhatóan egyaránt felelősek szenzibilizálás kapcsán rhinitis allergica, asthma bronchiale, atopiás dermatitis és kontaktekzema kialakulásáért, fellángolásáért $[3,18]$. Ezen megbetegedések diagnosztikáját, differenciáldiagnosztikáját és kezelésük alapjait a háziporatkafélék családját bemutató fejezetben részleteztük.

\section{A szőrtüszőatka-félék családja}

A szőrtüszőatkák közül a hazánkban is fellelhető Demodex folliculorum hominis és Demodex brevis terjedt el embereken. A szemmel nem látható obligát ektoparaziták a faggyúmirigyekben gazdag testtájakon, a pilosebaceus egységben találhatók meg. Prevalenciájuk egészséges felnőttek esetén 23-100\% közötti értékeken mozog [3, 28]. Az életkor előrehaladtával számuk növekszik a bőrben. A legtöbbször nem okoznak tünetet [28]. A szőrtüszőatkák által kialakított kórképeket összefoglalóan demodicosisnak nevezik. A demodicosisnak megkülönböztetjük a primer és a szekunder formáját. Primer demodicosisban az atkák önmagukban felelősek a tünetek kialakulásáért, melyek gyakran 40 év fölötti egyéneken, elsősorban férfiakon észlelhetők, jellemzően az arcon, aszimmetrikusan, csoportos papulák, papulopustulák formájában. Primeren kialakíthatnak perioralis, periorbitalis és periauricularis demodicosist is. Szekunder típusában a meglévő bőr- vagy szisztémás betegség talaján a szőrtüszőatkák kifejezett elszaporodása a tünetek perzisztálását, fellángolását okozhatja [29]. Kimutatták nagyobb számban való előfordulásukat perioralis dermatitisben, seborrhoeás dermatitisben, acne vulgarisban, papulopustularis rosaceában és immunszuppresszív állapotokban [29, 30]. Ritkán a szempillák elvesztését okozhatják [29]. A diagnózis felállításában a klinikai kép mellett elsősorban a celluxcsíkkal történő mintavétel és ennek mikroszkópos vizsgálata segíthet, kivételes, atípusos esetben bőrbiopszia során a szövettani metszeteken azonosíthatók a szőrtüszőatkák [28]. Differenciáldiagnosztikai szempontból fontos elkülöníteni a primer demodicosisokat az acne papulopustulosától, a rosacea papulopustulosától, a perioralis és a periorbitalis dermatitistől, a follicularis pyodermáktól, a Gram-negatív folliculitisektól és az acneiformis gyógyszererupcióktól [3, 29]. Figyelmet érdemel a már ismert acne vulgaris, seborrhoeás dermatitis, rosacea papulopustulosa, perioralis és periorbitalis dermatitis esetén a szőrtüszőatkák nagy számban való elszaporodása [29, 30]. 
A demodicosisok kezelésére lokálisan hazánkban az 1\%-os ivermektinkrém érhető el [31]. Korábban forgalomban volt 7,5\%-os metronidazolkrém és -gél, de ezek jelenleg nem kaphatók [32]. A scabies kezelésében alkalmazandó lokális akaricidek (5\%-os permetrinkrém, 2530\%-os benzil-benzoát-emulzió, 10\%-os krotamitonkrém) demodicosisban való hatékonysága kérdéses, ezek alkalmazása elsősorban törzsi lokalizációban lenne kedvező. Szisztémásan metronidazol adható, illetve szisztémásan ivermektin hatékony lenne, Magyarországon azonban jelenleg nincs forgalomban. Kérdéses a rosacea kezelésében használatos makrolidek és tetraciklin parazitaellenes hatása, az utóbbiról feltételezik, hogy akadályozza a szőrtüszőatkák proliferációját [29].

\section{A szőratkafélék családja}

A hazánkban is előforduló szőratkák az epidermisen, szőrszálakon élnek, és a „sétáló korpa” kialakulásáért felelősek kutyák, macskák, nyulak esetében. Közvetlen kontaktus révén emberre átjuthatnak. Az expozíció helyén viszkető, erythemás papulák, plakkok, olykor vesiculák, bullák jelentkezhetnek. A diagnosztizálásban fontos a tünetes (hámló, foltos szőrvesztésű, töredezett szőrú) háziállatok felderítése. Az állatorvosok az anamnézis, a klinikai kép és az adhéziós (például cellux-) technikával szerzett minta fénymikroszkópos vizsgálatával tudják diagnosztizálni a betegséget házi kedvenceinknél. A háziállatok kezelésére elsősorban lokális akaricidek alkalmazandók, illetve peroralis ivermektin lenne megfelelő. A kezelést követőn a humán megbetegedés spontán szûnése várható. Embereknél lokális kortikoszteroid és kifejezett viszketés esetén peroralis antihisztamin használatos. A ritka humán esetekben a tünetek elkülönítendők más ízeltlábúak csípéseitől, az ekzemák különböző altípusaitól, bullosus reakció fellépésekor pedig az autoimmun hólyagos bőrbetegségektől [33].

\section{A bársonyatkafélék családja}

A Trombicula nemzetségbe tartozó atkák a trombidiosist okozzák. Primer hordozóik a rágcsálók. Magas fúben, bozótosokban, szalmakazlakban, gabonákon fordulnak elő. Hazánkban szezonálisan, késő nyáron, ősszel, főleg aratást követően okoznak tüneteket, a leggyakrabban mezőgazdasági munkásokon vagy kertészeken. A lárvák a ruha által fedett területen, deréktájon, bokáknál, hajlatoknál jutnak be a bőrbe, táplálkoznak, majd leesnek [3]. Órákkal később intenzív viszketés, a csípés helyén szúrcsatornával rendelkező erythemás vagy haemorrhagiás maculák, papulák, seropapulák, urticák jelentkeznek, melyek elsősorban más ízeltlábúak csípéseitől különítendők el $[3,9]$. A ruhával fedett részen lévő tünetek a lokalizáció alapján szúnyogcsípéstől differenciálhatók. Megelőzésre repellensek használhatók, a kezelés tüneti [9].

Magyarországon ugyan nem fordul elő, de a szubtrópusokon a tsutsugamushi láznak, vagyis a bozóttífusz kórokozójának, a Rickettsia tsutsugamushi baktériumnak lehet a bársonyatka a vektora [3]. A csípés helyén gyakran pörkkel fedett erózió, papula észlelhető (60-90\%), melyet láz, regionális, majd generalizált lymphadenopathia követ. A betegek felénél a törzsön erythemás maculák, majd papulák jelentkeznek [4]. Meningoencephali-

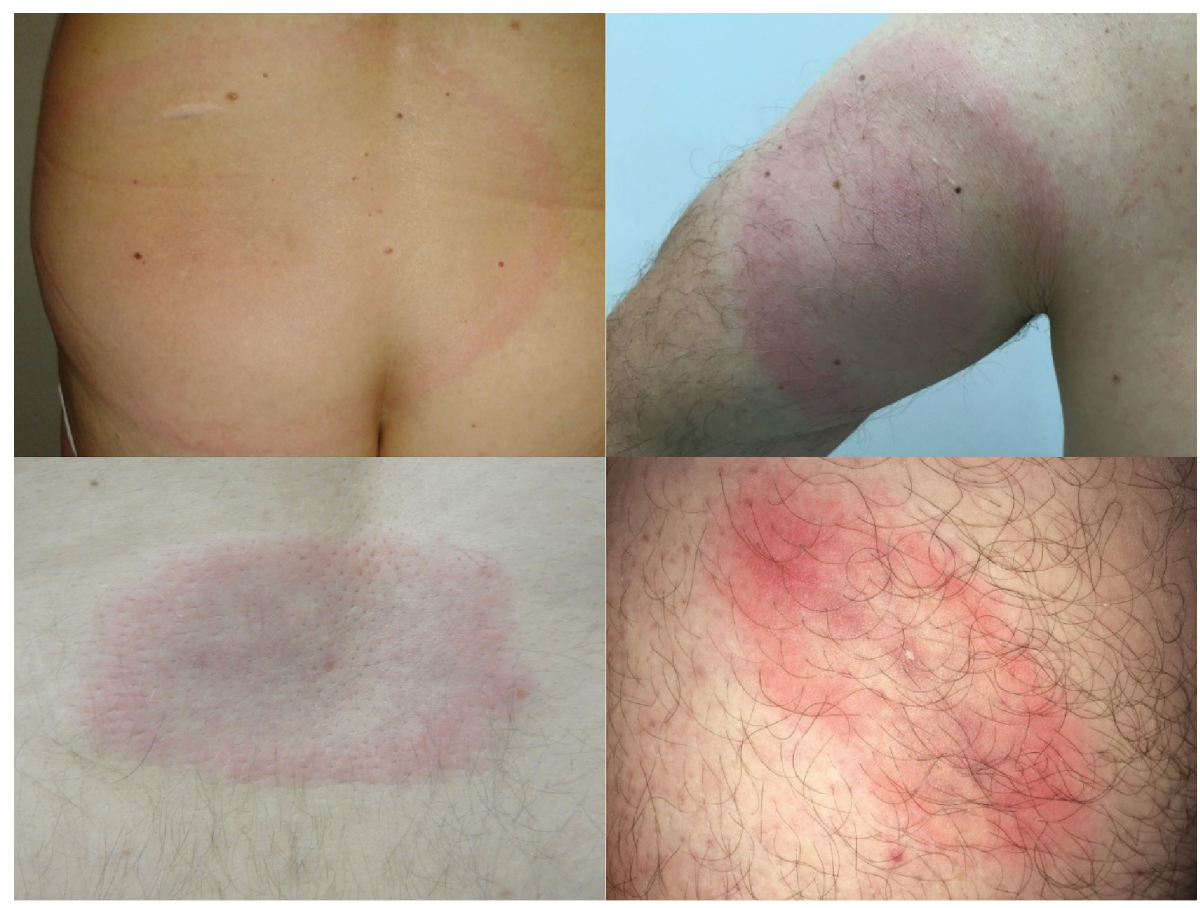


tis, pneumonitis, májelégtelenség alakulhat ki. Változó (0-60\%) halálozással jár [34]. A tünetek mellett a szerológiai vizsgálatok segítik a diagnosztizálást. A vírusexanthemáktól (enterovírus, Epstein-Barr-vírus, parvovírus B19, dengue-vírus) és a rickettsiák okozta foltos láztól különítendő el [4]. Kezelésére elsőként választandó a doxiciklin, várandósok és gyermekek számára azitromicin javasolt $[4,34]$.

\section{A kullancsfélék családja}

Az atkák alosztálya kullancsalakúak rendjének kullancsfélék (Ixodidae) családjához több száz faj tartozik. Fejlődésük négy stádiumra osztható: pete, lárva, nimfa és imágó. Mindegyik stádiumban szükségük van a vérszívásra [2]. Klimatikus tényezők (hőmérséklet, páratartalom) határozzák meg a növekedésük ütemét, mely akár évekig eltarthat. Az egyes kullancsfajok előfordulásának gyakorisága geográfiai tényezőktől függ. Hazánkban eddig az Ixodidae család 27 faját azonosították, melyek közül 21-et tekintenek honosnak, 6-ot pedig importáltnak [35]. A kullancsok közegészségügyi szempontból jelentôsek, mivel számos vírusnak és baktériumnak a vektorai [4]. Magyarországon a humán megbetegedéseket okozó Borrelia burgdorferi, Borrelia afzelii, Borrelia spielmanii, Francisella tularensis és a kullancsencephalitis-vírus terjesztésében van szerepük $[34,36]$. Külföldön a babesiáknak, az ehrlichiáknak, az orientáknak, a rickettsiáknak, az anaplasmáknak, a neorickettsiáknak, a neoehrlichiáknak és legalább 160 vírusnak a vektorai [4, 37]. A vérszívás révén táplálkozó ektoparazita kullancsok csípése fájdalmatlan, a legtöbbször csak enyhe lokális reakció, centrálisan szúrcsatornát tartalmazó erythemás macula vagy papula látható [3]. A diagnózis felállításában az anamnézis - utazások -, tünetek mellett a szerológiai vizsgálatok segíthetnek [4]. A téma terjedelméból adódóan a következőkben a kullancsok által terjesztett hazai humán megbetegedéseket tárgyaljuk.

A Lyme-borreliosist fóként az Ixodes ricinus (közönséges kullancs) által terjesztett Borrelia burgdorferi, ritkábban Borrelia afzelii és Borrelia spielmanii fajok okozzák Magyarországon [36]. Hazánkban 2015 és 2019 között évente 1420-tól 1610-ig terjedő számban jelentettek Lyme-kórt [38]. Három stádiumát különböztetjük meg (korai lokalizált, korai disszeminált, késői perzisztáló) [34]. A korai lokalizált szakban (nem minden esetben) erythema migrans jelentkezhet (3. ábra), mely 24 óra lappangási idő után, legalább 3 napig fokozatosan növekvő, legalább $5 \mathrm{~cm}$ átmérőjű ovális erythemás folt. Az elváltozás széli irányban növekszik, átmérője elérheti akár az 1 métert. Jellegzetes céltáblarajzolatot ölthet, hetekig, hónapokig megmaradhat. Az alsó végtagokon gyakran bevérzett lehet. Ritkán multiplexen jelentkezik [39]. A kullancs a szúrása során érzéstelenítő anyagot juttat a bőrbe, így a beteg a csípést nem észleli, emiatt a korai bőrelváltozásnak gyakran nem tulajdonít jelentőséget, vagy nem hozza összefüggésbe a csípéssel [3]. Az erythema migrans összetéveszthető más ízeltlábúak csípési reakcióival, egyéb anularis (gyưrúszerú) erythemákkal - mint az erythema annulare centrifugum és a granuloma annulare -, illetve mycosissal és lokalizált sclerodermával/morpheával. A Lyme-kór korai stádiumának ritka bőrtünete a Borrelia-lymphocytoma (lymphadenosis cutis benigna), mely fájdalmatlan, livid erythemás, tömött, kezeletlenül több mint egy hétig fennálló papula vagy nodulus. Gyermekeknél jellemzően fülkagylón, fülcimpán, pubertáskorban és felnőtteknél a mamillán észlelhető. Különböző ízeltlábúak csípésétől differenciálandó [39]. A korai disszeminált szakban bőrtünetként többszörös, gyưrüszerû erythemás maculák, periorbitalis erythema, lymphocytoma, diffúz urticariformis erythema jelentkezhet [3]. Ebben a stádiumban korai neurológai manifesztációk, úgymint lymphocytás meningitis, facialis paresis, ritkábban abducens paresis, radiculopathia, perifériás neuropathia, mononeuropathia multiplex alakulhat ki, melyek számos neurológiai kórképtől (organikus és infekciózus) különítendők el. Lyme-carditis következtében atrioventricularis vezetési blokk jelentkezhet fluktuálóan. A nem diagnosztizált és nem kezelt késői szakban Lyme-arthritis jöhet létre. Egy vagy néhány nagyízület lehet érintett, az ízületi gyulladás spontán szűnhet, majd visszatérhet. A kezeletlen esetekben ritkán késői neurológiai eltérések észlelhetők, ilyen az encephalopathia, a kognitív funkciók zavara, a perifériás neuropathia és az encephalomyelitis [34]. Szintén késői szakban jelentkezhet az acrodermatitis chronica atrophicans, mely a végtagokra, elsősorban az alsó végtagok feszítőfelszínére lokalizálódó, kezdetben tészta tapintatú, majd foltosan atrofizáló plakk [39]. Az acrodermatitis chronica atrophicans differenciáldiagnosztikájában a krónikus vénás elégtelenséghez társuló atrophia és hiperpigmentáció, az atrophie blanche, a krónikus ekzema és a lipodermatosclerosis jön szóba [3, 39].

A korai szakban az erythema migranst a klinikai kép alapján diagnosztizáljuk. A korai disszeminált és a késői szakaszban alkalmazhatók a szerológiai vizsgálatok, azonban sem specificitásuk, sem szenzitivitásuk nem kielégítő $[34,39]$. Két lépcsőben javasolt a szerológia végzése: először ELISA-technikával, majd ennek pozitivitása vagy kétes értéke esetén Western blottal [39]. Neuroborreliosis gyanúja esetén a savó és a liquor együttes vizsgálata szükséges. Ízületi érintettség esetén a synovialis folyadék is vizsgálandó [34].

Kezelése erythema migrans és carditis esetén amoxicillin (per os $3 \times 500 \mathrm{mg} 21$ napig) vagy doxiciklin (per os $2 \times 100 \mathrm{mg}$ 14-21 napig) vagy cefuroxim (per os $2 \times 500$ mg 21 napig), neuroborreliosis esetén cefuroxim (intravénásan $1 \times 2$ g 14-21 napig), arthritis esetén amoxicillin (per os $3 \times 500 \mathrm{mg} 28$ napig) vagy doxiciklin (per os $2 \times 100 \mathrm{mg} 28$ napig), arthritis esetén per os terápia hatástalanságakor ceftriaxon (intavénásan $1 \times 2$ g 14-28 napig). A makrolidek kevésbé hatékonyak, így első választásként nem ajánlottak. Várandósoknak, szoptató 
anyáknak, 8 éves kor alatti gyermekeknek doxiciklin nem adható [34].

A bejelentési kötelezettség alá tartozó tularaemiát hazánkban 2015 és 2019 között évente 11-36 esetben azonosították [38]. A tularaemiát a vektor szerepü kullancsok, szúnyogok vagy rágcsálók által terjesztett Francisella tularensis okozza. A vektorok csípése révén ulceroglandularis formában az enyhe, influenzaszerú tünetek mellett barnásvörös, mérsékelten tömött, néhány nap alatt kifekélyesedő, lymphadenopathiával járó nodusok jelentkezhetnek, melyek a szifiliszes primer affekcióhoz és a tuberculosis ulcerosa cutishoz hasonlíthatnak [3, 34]. Kezelésében ciprofloxacin, doxiciklin alkalmazható [34].

A kullancsencephalitis-vírus okozta megbetegedés az utóbbi 5 esztendőben évente 16-32 esetben került diagnosztizálásra [38]. Nyáron és ősszel gyakoribb. A csípést követő 7-14 napos lappangási idő után felső légúti infekciónak megfelelő tünetek észlelhetők. Néhány napos panaszmentes időszakot követően az idegrendszer érintettségére utaló tünetek mellett visszatér a láz. Kialakulhat lymphocytás meningitis, meningoencephalitis, myelitis vagy ezek kombinációja. A klinikai kép az egészen enyhe formától a súlyos, intenzív ellátást igénylő, esetenként halálos kimenetelig változhat. Diagnosztizálására a tünetek mellett a liquorból víruskimutatással, a liquor és a savó szerológiai vizsgálatával van lehetőség, mely segítséget nyújt az egyéb kórokozók okozta encephalitis elkülönítésére. Terápiája szupportív, tüneti. A betegség aktív immunizálással megelőzhető [34].

\section{Következtetés}

Az atkák alosztálya nagyon változatos. Rendjei között számos élőhelyi és életmódbeli eltérés van, ebből adódóan különféle mechanizmusokkal alakíthatnak ki betegségeket $[2,3]$. A rühatkaalakúak rendjén belül a rühatkák közvetlen, szoros kontaktussal terjedően, a bőrben elszaporodva, a háziporatkák és a készletatkák a környezetünkben túlérzékenységi reakció révén több, világszerte és hazánkban is gyakori allergiás megbetegedés létrejöttéért felelősek $[9,18,21]$. A bársonyatka-alakúak családján belül Magyarországon a bársonyatkák embereken szezonális, elsősorban munkavégzéssel kapcsolatos, föként banális, a humán pilosebaceus egységben élő rezidens szőrtüszőatkák alapbetegségtől és hajlamosító tényezőktől függően nagy számban elszaporodva különféle kórképeket, a szőratkák házi kedvenceinkről véletlenül átjutva spontán szúnő tüneteket okozhatnak $[9,28$, 33]. A kullancsalakúak rendjének tagjai vektorként a fájdalmatlan csípésük által rengeteg kórokozó átvitelében játszanak szerepet $[34,39]$. Az atkák méretükben parányiak ugyan, de világszerte elterjedtek, és különféle súlyosságú megbetegedésekért felelősek. Ezen kórképek közegészségügyi, járványtani és allergológiai jelentősége kiemelkedő [11, 17, 34].
Anyagi támogatás: A közlemény megírása anyagi támogatásban nem részesült.

Szerzői munkamegosztás: B. D.: Adatgyüjtés, irodalomkutatás, a kézirat elkészítése. N. G.: Adatgyưjtés, irodalomkutatás, a közlemény elkészítésének szakmai iránymutatása. B. T.: Szövettani vizsgálat. A cikk végleges változatát valamennyi szerző elolvasta és jóváhagyta.

Érdekeltségek: A szerzőknek nincsenek érdekeltségeik.

\section{Köszönetnyilvánítás}

A szerző́k köszönetüket fejezik ki dr. Károlyi Zsuzsánnának a kézirat kritikus átolvasásáért és $d r$. Mórocz Istvánnak a szövettani metszetről készített fotóért.

\section{Irodalom}

[1] Szatmári Zs. Arachnidae class. In: Molnár K. (ed.) Introduction to zoology. [Pókszabásúak (Arachnida) osztálya. In: Molnár K. (szerk.) Bevezetés az állattanba.] ELTE Eötvös Kiadó, Budapest, 2012; pp: 248-251. [Hungarian]

[2] Farkas J. Phylum: arthropoda. In: Farkas J. (ed.) Animal taxonomy practicals. [Törzs: Arthropoda-ízeltlábúak. In: Farkas J. (szerk.) Állatrendszertani gyakorlatok.] ELTE Eötvös Kiadó, Budapest, 2013; pp: 61-68. [Hungarian]

[3] Kárpáti S, Gyulai R, Kemény L, et al. Dermatology and venereology. [Bőrgyógyászat és venereológia.] Medicina Könyvkiadó, Budapest, 2020. [Hungarian]

[4] Walker DH, Blanton LS. Rickettsial diseases. In: Bolognia JL, Schaffer JV, Cerroni L. (eds.) Dermatology. Elsevier Saunders, Philadelphia, PA, 2017; pp: 1319-1327.

[5] Anderson KL, Strowd LC. Epidemiology, diagnosis, and treatment of scabies in a dermatology office. J Am Board Fam Med. 2017; 30: 78-84

[6] Balogh E, Farkas I, Varga E, et al. Scabies. The importance and difficulties of differential diagnosis. [Scabies. A differenciáldiagnosztika jelentősége és nehézségei.] Bőrgyógy Venerol Szle. 2015; 91: 118-122. [Hungarian]

[7] Zou Y, Hu W, Zheng J, et al. Nail infestation: an atypical presen tation of typical scabies. Lancet 2018; 391: 2272.

[8] Magyari NK, Szenes É, Egyházi Zs, et al. Scabies norvegica (crusted scabies). Case report. [Scabies norvegica (crustosus scabies). Betegbemutatás.] Bőrgyógy Venerol Szle. 2014; 90: 2429. [Hungarian]

[9] Solymosi Á, Hetesi K. Arthropods caused diseases. In: Szalai Zs. (ed.) Pediatric dermatology. [Ízeltlábúak okozta kórképek. In: Szalai Zs. (szerk.) Gyermekbőrgyógyászat.] Medicina Könyvkiadó, Budapest, 2020; pp. 380-382. [Hungarian]

[10] Aukerman W, Curfman K, Urias D, et al. Norwegian scabies management after prolonged disease course: a case report. Int J Surg Case Rep. 2019; 61: 180-183.

[11] Pecze T, Sziray Á, Lengyel E, et al. Ivermectin use in Norwegian scabies - experiences in a nosocomial outbreak. [A scabies norvegica ivermectin kezelése - tapasztalatok egy nosocomialis járvánnyal kapcsolatban.] Bőrgyógy Venerol Szle. 2008; 84: 25-28. [Hungarian]

[12] Mittal A, Garg A, Agarwal N, et al. Treatment of nodular scabies with topical tacrolimus. Indian Dermatol Online J. 2013; 4: $52-53$.

[13] Luo ZY, Zeng M, Gao Q, et al. Case report: bullous scabies in two children below 10 years. Am J Trop Med Hyg. 2017; 97: $1746-1748$.

[14] Guldbakke KK, Khachemoune A. Crusted scabies: a clinical review. J Drugs Dermatol. 2006; 5: 221-227. 
[15] Hay RJ. Scabies - learning from the animals. J Eur Acad Dermatol Venereol. 2004; 18: 129-130.

[16] Zeytun E, Doğan S, Ünver E, et al. Evaluation of Dermatophagoides pteronyssinus (Trouessart) and D. farinae Hughes (Acari: Pyroglyphidae) sensitivity in patients with allergic rhinitis: a comparative study. System Appl Acarol. 2018; 23: 206-215. [Correction: System Appl Acarol. 2018; 23: 404.]

[17] Matricardi PM, Kleine-Tebbe J, Hoffmann HJ, et al. EAACI molecular allergology user's guide. Pediatr Allergy Immunol. 2016; 27(Suppl 23): 1-250.

[18] Calderón MA, Linneberg A, Kleine-Tebbe J, et al. Respiratory allergy caused by house dust mites: what do we really know? J Allergy Clin Immunol. 2015; 136: 38-48.

[19] Yang L, Zhu R. Immunotherapy of house dust mite allergy. Hum Vaccin Immunother. 2017; 13: 2390-2396.

[20] Ministry of Healthcare's guideline about the diagnostics and treatment of rhinitis. Az Egészségügyi Minisztérium Szakmai Irányelve a rhinitis diagnosztikájáról és kezeléséről.] Eü Közl. 2010; 60: 1584-1604. [Hungarian]

[21] Calderón MA, Kleine-Tebbe J, Linneberg A, et al. House dust mite respiratory allergy: an overview of current therapeutic strategies. J Allergy Clin Immunol Pract. 2015; 3: 843-855.

[22] Pónyai Gy. Adult atopic detmatitis: epidemiology, provocing factors and prognosis, clinical features and differential diagnosis. [A felnőttkori atópiás dermatitis: epidemiológia, provokáló faktorok és prognózis, klinikai tünetek és differenciáldiagnózis.] Bőrgyógy Venerol Szle. 2017; 93: 218-224. [Hungarian]

[23] Sur DK, Plesa ML. Treatment of allergic rhinitis. Am Fam Physician 2015; 92: 985-992.

[24] Ezzo D. Treatment and managed care issues of atopic dermatitis. Am J Manag Care 2017; 23(8 Suppl): S124-S131.

[25] Gibeon D, Menzies-Gow A. Recent changes in the drug treatment of allergic asthma. Clin Med (Lond). 2013; 13: 477-481

[26] OGYÉI National Institute of Pharmacy and Nutrition. Manual of Xolair. [Országos Gyógyszerészeti és Élelmezés-egészségügyi Intézet. Xolair alkalmazási elő́rás.] Available from: https:// ogyei.gov.hu/gyogyszeradatbazis\&action=show_details\&item= 131625 [accessed: February 10, 2009]. [Hungarian]

[27] Muraro A, Werfel T, Hoffmann-Sommergruber K, et al. EAACI food allergy and anaphylaxis guidelines: diagnosis and management of food allergy. Allergy 2014; 69: 1008-1025.

[28] Rather AP, Hassan I. Human Demodex mite: the versatile mite of dermatological importance. Indian J Dermatol. 2014; 59: 60-66.

[29] Chen W, Plewig G. Human demodicosis: revisit and a proposed classification. Br J Dermatol. 2014; 170: 1219-1225.
[30] Karabay EA, Çerman AA. Demodex folliculorum infestations in common facial dermatoses: acne vulgaris, rosacea, seborrheic dermatitis. An Bras Dermatol. 2020; 95: 187-193.

[31] OGYÉI National Institute of Pharmacy and Nutrition. Manual of Soolantra cream. [Országos Gyógyszerészeti és Élelmezésegészségügyi Intézet. Soolantra krém alkalmazási előirat.] Available from: https://ogyei.gov.hu/gyogyszeradatbazis\&action= show_details\&item=107233 [accessed: July 1, 2020]. [Hungarian]

[32] OGYÉI National Institute of Pharmacy and Nutrition. Manual of Rozex gel. [Országos Gyógyszerészeti és Élelmezés-egészségügyi Intézet. Rozex gél alkalmazási előirat.] Available from: https://www.ogyei.gov.hu/gyogyszeradatbazis\&action=show details\&item=19053 [accessed: June 12, 2015]. [Hungarian]

[33] Reynolds HH, Elston DM. What's eating you? Cheyletiella mites. Cutis 2017; 99: 335; 336; 355 .

[34] Ludwig E. Infectology. [Infektológia.] Medicina Könyvkiadó, Budapest, 2020. [Hungarian]

[35] Hornok S, Kováts D, Horváth G, et al. Checklist of the hard tick (Acari: Ixodidae) fauna of Hungary with emphasis on host-associations and the emergence of Rhipicephalus sanguineus. Exp Appl Acarol. 2020; 80: 311-328.

[36] Földvári G, Farkas R, Lakos A. Borrelia spielmanii erythema migrans, Hungary. Emerg Infect Dis. 2005; 11: 1794-1795.

[37] Bartíková $P, V$ Holíková $P$, Kazimírová $M$, et al. Tick-borne viruses. Acta Virol. 2017; 61: 413-427.

[38] National Public Health Center. Data of the declared infectious diseases in 2019. [Nemzeti Népegészségügyi Központ. A 2019. évben bejelentett fertőző betegségek adatai.] Available from: https://www.antsz.hu/data/cms96760/OSAP_Fertozo_ 2019_honlapra.pdf [accessed: June 17, 2020]. [Hungarian]

[39] Professional College of Infectious Diseases. The guideline of the National Resources Ministry about the clinical and laboratory diagnosis and treatment of Lyme borreliosis. [Infektológiai Szakmai Kollégium. A Nemzeti Erőforrás Minisztérium szakmai irányelve a Lyme borreliosis klinikai és laboratóriumi diagnosztizálásáról és kezelésérool.] Eü Közl. 2011; 61: 1386-1393. [Hungarian]
(Budai Dóra dr., Miskolc, Csabai kapu 9-11., 3529 e-mail: dorabudai@gmail.com)

A cikk a Creative Commons Attribution 4.0 International License (https://creativecommons.org/licenses/by/4.0/) feltételei szerint publikált Open Access közlemény, melynek szellemében a cikk bármilyen médiumban szabadon felhasználható, megosztható és újraközölhető, feltéve, hogy az eredeti szerző és a közlés helye, illetve a CC License linkje és az esetlegesen végrehajtott módosítások feltüntetésre kerülnek. (SID_1) 